\title{
Is the Scholarship of Engagement a Meaningful Approach to Foster Change in Community Development Education? Field Notes from Three Community/University Partnerships
}

\author{
Lorena M. Estrada-Martínez ${ }^{1}$ - Antonio Raciti ${ }^{1}$ - Kenneth M. Reardon ${ }^{1}$.

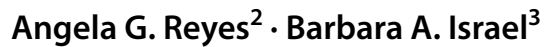

Received: 5 August 2020 / Accepted: 2 March 2021 / Published online: 6 April 2021

(C) The Author(s) 2021

\begin{abstract}
Pedagogical approaches in community-engaged education have been the object of interest for those aiming at improving community health and well-being and reducing social and economic inequities. Using the epistemological framework provided by the scholarship of engagement, this article examines three nationally recognized and successful examples of community-university partnerships in the fields of community planning and public health: the East St. Louis Action Research Project, the South Memphis Revitalization Action Project, and the Detroit CommunityAcademic Urban Research Center. We review and compare how these partnerships emerged, developed, and engaged students, community partners, and academic researchers with their local communities in ways that achieved positive social change. We conclude by highlighting common elements across the partnerships that provide valuable insights in promoting more progressive forms of communityengaged scholarship, as well as a list of examples of what radical forms of community-engaged education may look like.
\end{abstract}

Keywords Community engagement · Community-university partnerships · Community-based participatory research $\cdot$ Detroit $\cdot$ Memphis $\cdot$ East St. Louis

Lorena M. Estrada-Martínez

lorena.estrada@umb.edu

1 Department of Urban Planning and Community Development, School for the Environment, University of Massachusetts Boston, Boston, MA, USA

2 Detroit Hispanic Development Corporation, Detroit, MI, USA

3 Department of Health Behavior and Health Education, School of Public Health, University of Michigan, Ann Arbor, MI, USA 


\section{Introduction}

One of the most severe problems confronting American cities today is the everincreasing income, wealth, and power disparities separating neighborhoods (Brownstein, 2020). These persistent inequalities have resulted in large differences in life expectancies, differential exposure to environmental contaminants, educational and occupational opportunities, access and availability to high-quality, affordable fresh foods and housing, to name a few (Healthy People, 2030). Some neighborhoods benefit from well-resourced schools and parks, efficient government services, local access to emergency and health services, and influence over elected officials, while others experience low-quality schools, governmental neglect, substandard housing, and ultimately deterioration of social relationships. Community development (Cameron \& Wasacase, 2017; Trickett \& Rauk, 2019) and public health (Syme \& Ritterman, 2009) scholars noted the critical role of community members' active participation in developing and implementing policies and interventions that aim to improve community health and well-being with an eye towards equity.

Colleges, universities, and medical centers are important anchor institutions called upon to support resident-led redevelopment efforts taking place in our most economically challenged communities (Birch et al., 2013). These institutions have typically pursued urban revitalization goals by working with community-based organizations and municipal agencies to develop comprehensive neighborhood plans to enhance overall community health and well-being (Phillips \& Wong, 2016; Healthy People, 2030). These community/university (C/U) partnerships seek to strengthen individual, institutional, and community-scale factors that improve our most distressed urban and rural communities' overall quality of life. The most successful of the more than 1,200 university-based community engagement centers and institutes established to advance community health and wellbeing reflect Ernest Boyer's holistic approach to the scholarship of engagement (Winthrop \& Dusst, 2020). This article examines the extent to which three highly regarded $\mathrm{C} / \mathrm{U}$ collaboratives have positively affected community health and wellbeing in their primary service areas while also offering student, faculty, and community participants transformational learning opportunities (Mezirow, 1991).

In his trailblazing work on the scholarship of engagement (Boyer, 1990, 1996), Ernest Boyer, the former president of the Carnegie Foundation, defined four significant areas needed to transform the academy into a "more vigorous partner in the search for answers to our most pressing social, civic, economic, and moral problems" (Boyer, 1996, p. 1). He invited scholars to go beyond the traditional mission of the academy by incorporating four primary forms of scholarships: the scholarship of discovery to push the boundaries of human knowledge, the scholarship of integration to realize innovative forms of collaboration between and among disciplines, the scholarship of application to regularly apply new knowledge in the real world, and the scholarship of teaching to activate reciprocal learning processes within the classroom. More than 20 years have passed since Boyer 
first described this expanded idea of scholarship. However, there are still many challenges on how to conceptualize and put them into practice (Campbell, 2012).

One of the most controversial elements of Boyer's four-sided notion of scholarship is related to teaching and its capacity to transform it into a dynamic practice that "encourages students to be critical, creative thinkers with the capacity to go on learning" (Boyer, 1990, p. 24). This perspective invites current and future generations of learners to become continuously engaged and practically involved in their field of study. During the late 1990s, this challenged colleges and universities to involve their classrooms in real-world problem-solving projects to provide students with a deeper understanding of organizational and community change processes. The engaged scholarship movement (Rhoads \& Howard, 1998) resulted in higher education institutions partnering with community members and institutions that sought to expand economic opportunities for those with the fewest resources. Early proponents believed this movement could improve conditions in distressed communities, democratize the knowledge production process, and reinvigorate civil society. They were confident it had the potential to become a type of reform that would offer a new horizon of possibilities for action outside of the current socioeconomic capitalist system (Gorz, 1970, p. 7).

The last three decades have witnessed the establishment and development of numerous $\mathrm{C} / \mathrm{U}$ partnerships under the banner of the scholarship of engagement. In the continuing struggle for social justice, not all forms of engagement have been successful. The way partnerships are designed or executed is sometimes an impediment to their fulfillment. In this regard, successful cases might offer essential lessons to inform approaches aiming at bringing the transformative power of the scholarship of engagement to its full potential. According to Boyer (1996), the scholarship of engagement formalizes an academic enterprise combining the scholarships of (1) discovery, (2) integration, (3) sharing and (4) application of knowledge. More specifically, Boyer was inviting academic institutions to renovate their ways of knowing by pushing the boundaries of human knowledge through research activities overlapping multiple set of disciplines (integration), by continually validating discoveries with students (sharing), and by newly generated knowledge for effectuation in the real world (application). Bringing the scholarship of engagement to its full potential means activating forms of knowing that are highly collaborative, involving different membership in and outside the academy to generate mutually beneficial benefits for students, faculty, researchers, and community partners involved.

This paper compares three US-based cases of $\mathrm{C} / \mathrm{U}$ partnerships that have produced significant research, teaching, and learning with transformative results for the community and university partners, and students involved. We briefly introduce types of $\mathrm{C} / \mathrm{U}$ collaborations and community-based participatory research as a model of cooperative principles based on social justice that addresses health and community well-being and learning within the context of power imbalances. We then review the origins, goals and objectives, participatory approaches and methodology, initiatives, and accomplishments of these C/U partnerships. The first two cases in East St. Louis, Illinois, and Memphis, Tennessee stem from partnerships between community-based organizations, local leaders, and departments of urban planning, community development, and architecture that aimed to address critical 
urban problems while enhancing the organizational capacity of local development corporations. The third case in Detroit, Michigan, is a health-focused partnership that brought together schools of public health, nursing and social work, a public health agency, an integrated health care system, and community-based organizations to address factors that determine health. By discussing and comparing the lessons learned, we conclude with some reflections useful to operationalizing transformative $\mathrm{C} / \mathrm{U}$ partnerships that are engaged in research and teaching and learning for social change both on campus and in the community.

\section{Community/University Partnerships for Social Change}

An early assessment of $\mathrm{C} / \mathrm{U}$ partnerships found these programs to be "normally distributed" across three types (Nye \& Schramm, 1999). Nye and Schramm discovered a modest number of partnerships focused on service projects chosen by campus partners to enhance their institutional reputations following various forms of institutional misbehaviors. Quietly assembling land in residential neighborhoods adjacent to their campuses in anticipation of future growth without community or municipal consultation and paternalistic, tokenistic approaches to community development are all too common forms of such institutional misbehaviors. They identified a more significant number of partnerships that pursued community research initiatives in response to needs articulated by grassroots organizations. In most of these cases, higher education institutions undertook this work using the "professional expert" model of community research (Whyte, 1982). This model tends to maintain campus researchers' privileged position over community leaders in designing and implementing the various phases of the research process. Finally, they located a limited number of partnerships that involved grassroots activists and university scholars in research, planning, and development efforts. These partnerships identified and disrupted the structural causes of critical urban problems by implementing a highly collaborative process in which campus researchers and community members function as equal partners.

Nye and Schramm argue that this latter category represents the best option to determine courses of actions through which systemic change might occur. However, necessary pre-conditions enabling these types of partnerships cannot be taken for granted. Collaborations between universities and community organizations might start with a simple and limited partnership that might fall into the second category identified in the report. Over time, reciprocal learning involving community leaders and university members may result in a shift from short-term problem-solving to systemic change and organizational capacity building. Along these lines, some have shared that meaningful partnerships maximize community benefits while providing educational opportunities for students involved. They build upon (1) an explicit willingness on both parts (communities and universities) to be engaged in such partnerships, (2) the existing capacity of the organizations involved to implement those partnerships, and, finally, (3) a broad set of higher educational structures that advance the implementation of C/U partnerships (Ferman \& Hill, 2004). 
The accountability of universities and their capacity to implement $\mathrm{C} / \mathrm{U}$ partnerships that work has been under scrutiny. This is mainly due to the potential negative consequences that ill-conceived and executed forms of engagement can have on affected communities and student learning outcomes. Some have highlighted the importance of academic institutions in making engagement a "core value" of their institution (Gibbons, 2003). This change goes beyond a mere claim of being an engaged institution. It implies earnest consideration of the power imbalance between universities and community members and organizations, which are supposed to be equal partners (Buys \& Bursnall, 2007). In particular, Ferman and Hill (2004) have found that university power relations within their local contexts can be problematic when implementing actions informed by those values. From this perspective, it is relevant to note that "meaningful interaction" between community and university has to mediate this divide. It must also actively involve community members in establishing the overall agenda and the decision-making processes through which institutions collaborate in specific projects (Benneworth, 2013).

Operationalizing the scholarship of engagement under these challenges is not an easy task. Most of the time, this endeavor falls into the hands of faculty whose primary mission within the academy reflects the core value of engagement for a better world. Successful examples from urban planning and public health have suggested practical lessons to implement $\mathrm{C} / \mathrm{U}$ partnerships fulfilling core values of engagement. Among those, the notion of "reciprocity" and "long-term" in community engagement processes represent foundational pre-conditions to achieve any structural change (Israel et al., 2013; Reardon, 2006; Seifer et al., 2009). Such scholars warn about the risks associated with short-term university projects with the ambition of changing something. They advocate for the importance to structure $\mathrm{C} / \mathrm{U}$ partnerships where decisions - those related to ideas, funding, control over the research projects, and the implementation of projects - are founded on a reciprocal agreement and benefit among campus and community partners over the long-term (Israel et al., 2013; Reardon, 2006; Seifer et al., 2009).

\section{Community-Based Participatory Research (CBPR)}

Community-based participatory research (CBPR) is an approach to community health and health inequities research that traces its roots to participatory action research and the popular education movements inspired by Paulo Freire (Wallerstein \& Duran, 2018). CBPR is centered on social justice and equity, and recognizes that health inequities will not disappear until social equity, embedded in social structures and power hierarchies, is achieved (Jones, 2018). C/U partnerships focused on health have increasingly used this approach. Resources and contexts ultimately determine the specific ways in which different partnerships execute their work. Nevertheless, a fundamental aspect of the CBPR principles is a cooperative process where all partners contribute equally at every stage of the research process, engage in co-learning, local capacity building, and systems development, and advance local community empowerment through strategic efforts (Israel et al., 1998, 2013; Wallerstein et al., 2018). At the heart of these 
principles is a deep commitment to power-sharing and translating research findings into interventions or policy changes that directly benefit local communities (Israel et al., 2013).

Effective partnerships require the active involvement of a diverse set of players to achieve maximum community participation and ownership, reciprocity, co-learning, and change. Successful, long-term partnerships require cultural humility and cultural safety. The first is a practice where all members acknowledge, consistently reflect upon and challenge the explicit and latent power imbalances that exist in $\mathrm{C} / \mathrm{U}$ alliances, taking concrete steps to address them (Israel et al., 2013). Through the process of cultural safety, partnerships promote awareness among community members and academic researchers of the broader historical, economic, political, and social contexts that determine health inequities, which subsequently contribute to mistrust within research collaborations. By adopting these two practices as integral to their relationships, the partnership engaged in "mutually beneficial and non-paternalistic partnerships" that successfully addressed the knowledge and skills gaps and the conscious and unconscious biases and attitudes that can undermine collaborative research (Israel et al., 2013).

\section{Transformative Learning Experiences}

Pedagogical approaches carried out within $\mathrm{C} / \mathrm{U}$ partnerships result in transformative learning and are best suited to fulfill the real engagement mission. In more practical terms, transformative learning occurs when people are exposed to a broad range of situations related to both the rational and emotional dimensions of knowledge (Dirkx et al., 2006). Such conditions are more likely to occur in settings where community members and university partners can reflect upon and address co-learning and power-sharing (Israel et al., 2013; Porter et al., 2015).

Community development and public health scholars of $\mathrm{C} / \mathrm{U}$ partnerships have documented how learning outcomes occur at various stages of the research and how they vary by participants' level of engagement in the process. For example, Balassiano (2011) described how facing "wicked problems" (Rittel \& Webber, 1973) in real life encourages students to re-frame and rethink their pre-conceived ideas regarding planning (Balassiano, 2011). Ezeonwu and colleagues (2014) described the "blended" learning models in public health, which features the use of face-toface and online reflection involving university and community partners (Ezeonwu et al., 2014). Reardon has pointed out how C/U partnerships might prompt the entire academic community to engage in deep self-reflection, or "epiphanies," on the meaning of their actions (Reardon, 2003). While these achievements in learning outcomes happen during the implementation of $\mathrm{C} / \mathrm{U}$ actions in the field, long-term and reciprocal partnerships can also foster significant institutional changes through learning moments that impact the academic structures involved in a $\mathrm{C} / \mathrm{U}$ partnership. In other words, $\mathrm{C} / \mathrm{U}$ partnership can generate a snowball effect in which learning moments occur at the individual, community, and institutional levels. For each of those levels, different types of learning might occur. 


\section{Brief Methodological Notes}

This paper provides an overview of three nationally recognized $\mathrm{C} / \mathrm{U}$ partnerships by comparing origins, goals and objectives, methodological and theoretical frameworks, major initiatives, and accomplishments. Special attention is given to the learning processes and outcomes fostered by these experiences. The lessons learned from each case can suggest a roadmap for action for those involved in similar projects to maximize the potential of their $\mathrm{C} / \mathrm{U}$ partnerships and their transformative learning goals. The presentation of cases draws from primary data collected by the authors through their direct involvement in those experiences. Additionally, secondary data has been drawn from a review of the reports and publications produced as outcomes of these partnerships.

The authors have been involved in these three projects in different capacities. Kenneth Reardon was the initiator and principal investigator (PI) of the two community planning projects feature in this review: the East St. Louis Action Research Project (ESLARP) carried out from 1999-2007 in East St. Louis (I.L.) and the South Memphis Revitalization Action Project (SoMeRAP), carried out in 2007-2012 in Memphis (T.N.). Antonio Raciti was involved in SoMeRAP during the academic year 2009-2010 and contributed to the implementation of some of the signature projects contained in the SoMeRAP plan. Lorena Estrada-Martínez was involved in the Detroit Community-Academic Urban Research Center as a graduate student research assistant from 2002-2004. Angela Reyes and Barbara Israel are founding members of the Detroit URC Board since it was established in 1995. Barbara Israel is also the Director of the Center.

\section{Partnerships for Change}

\section{The East St. Louis Action Research Project (ESLARP)}

In the spring of 1987, State Representative Wyvetter G. Younge (D-East St. Louis) was appointed Chair of the Illinois State Legislature's Higher Education Finance Sub-Committee. Shortly after that, she informed Stanley O. Ikenberry Jr., then-President of The University of Illinois, that she was unwilling to support the University's annual and capital budgets until his administration demonstrated its commitment to urban public service in severely distressed communities. Keenly aware of the necessity of securing Representative Younge's support for the University's budgets, Dr. Ikenberry encouraged the Provost of its Champaign-Urbana Campus to make $\$ 100,000$ available to faculty willing to undertake community-based research in East St. Louis. In the fall of 1987, architecture, landscape architecture, and urban planning faculty from UIUC's College of Fine and Applied Arts initiated the Urban Extension and Minority Assistance Project (UEMAP) in East St. Louis to undertake this work (for a complete account of this project see Reardon, 2019). 


\section{Goal and Objectives}

UEMAP's primary goal was to support research to identify innovative policy, planning, and design solutions to the wicked environmental, economic, and social problems confronting residents of this once prosperous riverfront community. UEMAP sought to achieve this goal by aggressively pursuing three main development objectives, including: (1) initiate interdisciplinary research to design and implement "best practice" solutions to the most critical problems undermining the city's overall quality of life; (2) prepare the next generation of socially-conscious architects, landscape architects, and urban planners for professional service in underserved communities; and, (3) engage East St. Louis youth in the design and building of projects to promote awareness of the personal, professional, and public service opportunities available within the design professions. Faculty hoped the pursuit of this last objective would result in much-needed diversity within the University's design programs.

Between 1987 and 1990, nearly 500 students participated in more than twodozen, credit-intensive studios investigating critical issues confronting the city's poorest neighborhoods. At the end of each semester, Representative Younge traveled to Champaign-Urbana to hear students present their research projects' results. Unfortunately, few of the proposals emerging from these studios generated significant interest among East St. Louis residents, institutional leaders, and elected officials. By the fall of 1990, UEMAP experienced difficulty recruiting students for its East St. Louis studios, prompting them to recruit new leadership who interviewed former students to gain a deeper understanding of their project experiences (see Reardon [2000] for a broader discussion on the professional-expert phase).

The former students questioned why the State Representative, who spent most of her time in the state capital, rather than community residents, decided which issues to be studied. They also wondered why UEMAP was not focused on supporting the environmental clean-up, food security, youth recreation, affordable housing, and arts and cultural projects being carried out by local organizations whose members appeared deeply invested in these efforts rather than spending time investigating student-generated revitalization schemes. Following these interviews, Professor Reardon and Ishag Shafiq interviewed a cross-section of East St. Louis leaders regarding their perceptions of the University's efforts. Very few of the leaders they interviewed appeared to be aware of the University's three-year extension project. When asked what they thought of the idea of a C/U development partnership, they were unenthusiastic, as reflected in the following comment by a long-term resident: "The last thing East St. Louis needs is another university professor telling us what any sixth-grader in town already knows."

\section{Partnership Process}

Most East St. Louis residents were skeptical about collaborating with the University, based on the lack of reciprocity and follow-through observed in the past. However, this was not true for the leaders of the Emerson Park Development Corporation. This newly formed community development corporation was eager to consider such involvement provided the campus agreed to a new "social contract," ensuring 
residents' significant voice within the partnership (Reardon, 1997). At an initial meeting to discuss a possible development partnership between the University and the community, Miss Ceola Davis, a highly respected community worker from the Lessie Bates Davis Neighborhood House, presented the following organizing principles for such a partnership:

"First, the residents of Emerson Park and their organization, EPDC, would determine the local issues to be addressed. Second, residents would be actively involved with the UIUC students and faculty at every step of the research and planning process. Third, UIUC's Department of Urban and Regional Planning must make a minimum 5-year commitment to working in the community. Fourth, the University must help EPDC gain access to regional funding agencies to secure the resources needed to implement local development projects. Fifth, the University must help EPDC create a nonprofit organization to sustain the community revitalization process after the University left the community." (Reardon, 2003, p. 118).

Reflecting upon these principles, Reardon and his colleagues abandoned UEMAP's "professional expert" model and adopted a participatory action research (PAR) approach designed to actively engaged residents, on an equal basis, at each step in the research process (i.e., problem identification and definition, data collection and analysis, plan implementation, evaluation). In doing so, they also embraced "reflective practitioner" methods to continually refine their collaborative research, planning, and design practices (Schön, 1984). They emphasized the importance of these decisions by changing the initiative's name from the Urban Extension and Minority Assistance Project (UEMAP) to the East St. Louis Action Research Project (ESLARP).

\section{Major Initiatives}

Between 1990 and 2007, UIUC faculty engaged more than 3,000 undergraduate and graduate students in a wide range of urban revitalization planning and design projects chosen by residents. The most significant of these included initiatives at the neighborhood scale that directly impacted the quality of life and well-being of participating residents. However, it also went beyond this, involving city and nationwide events with the potential of impacting urban areas outside of East St. Louis. By starting with the most immediate and urgent needs, the partnership carried out more than 200 neighborhood clean-ups, community beautification, playground, park, trail design and construction, community facilities restorations, home painting, renovation, and construction projects. Additionally, it provided technical assistance to enhance the organizing, planning, design, development, and management capacity of neighborhood organizations, community development corporations, and faithbased organizations in East St. Louis. The partnership generated a series of planning documents that, over the years, have supported the community in advancing their goals. The list includes (1) the completion of comprehensive revitalization plans for the City's Emerson Park, Lansdowne, Winstanley-Industry Park, Edgemont, Olivette Park, Alta Sita, and South End neighborhoods; (2) the creation of master plans for the Parsons Place Residential Development and the Eagles' Nest Veteran's Housing Project; (3) the preparation of a feasibility study that generated the data that 
led to the extension of St. Louis' Metrolink to East St. Louis dramatically expanding access to living-wage jobs, educational services, and health care for East St. Louis residents.

Furthermore, the partnership (1) sponsored two highly publicized national urban transformation conferences in East St. Louis hosted by Planners Network in 1996 and the U.S. Department of Housing and Urban Development in 1999; (2) formed and trained a city-wide network of grassroots activists, human service professionals, and faith-based leaders committed to redistributive development policies and participatory planning processes; and, finally, (3) fostered the training of hundreds of planning and design students committed to revitalizing the nation's most economically distressed communities through participatory planning and design.

\section{Accomplishments}

Due, in part, to the success of these efforts, ESLARP was able to undertake a study evaluating the benefits and costs of extending St. Louis' MetroLink through East St. Louis to Scott Air Force Base in O'Fallon, Illinois. This multi-million dollar public investment provided thousands of transit-dependent East St. Louis residents with dramatically enhanced access to living-wage jobs in Downtown St. Louis and the Lambert International Airport District. This investment also generated significant interest in transit-oriented-development in Emerson Park. The Emerson Park Development Corporation, with ESLARP's assistance, capitalized on this interest to attract McCormack, Baron, and Salazar, to design and build Parsons Place - a 140unit mixed-income, mixed-finance housing development. The success of this effort, in turn, led to the subsequent construction of Jazz Place, a mixed-use building housing a small-scale grocery and 90-units of senior housing at Emerson Park's 15th Street MetroLink Station adjacent to Parsons Place.

ESLARP's community leaders and campus participants co-created a new model of community planning well-suited for communities where there are significant economic and educational differences between the majority of local leaders seeking change and the university personnel supporting their efforts. The partnership's history shows how the resident-led process brought the community of learners to question pre-conceived ideas of what and how community planning should be pursued. This fertile ground fostered the conceptualization of "empowerment planning" as the integration of action research, community organizing, and popular education (Reardon, 2005). This was instrumental in changing the structure of studio courses at UIUC, which were designed as a series of multi- and interdisciplinary studios focused on the same problem area to foster significant change over the years (Reardon, 1997).

ESLARP has been recognized as one of the most influential community development projects of the late twentieth century. The project's reputation is based upon its success in using participatory action research to overcome the deep skepticism regarding the possibilities for change in "Rust-Belt" cities, such as East St. Louis, among urban policy-makers and public and private funders. Local leaders, UIUC faculty, and students co-produced neighborhood plans, project proposals, and urban designs that generated tens of millions of dollars in local, state, and federal funding. 
In the long run, learning "epiphanies" (Reardon, 2003) brought the partnership to reflect upon the powerful meaning of truly engaged academic institutions, which led to establishing a neighborhood college in East St Louis, and to affect students' careers formerly involved in ESLARP. Many of them subsequently dedicated their professional careers to support resident-led change in severely distressed communities using empowerment planning methods as a result of the ESLARP experiences.

\section{South Memphis Revitalization Action Project (SoMeRAP)}

In the summer of 2008, Reverends Kenneth and Marilyn Robinson, co-pastors of St. Andrew A.M.E. Church, in Memphis, TN, invited The Consilience Group, SelfTucker Architects, The Works Inc. Community Development Corporation, the City of Memphis' Community Development Agency, the Hyde Family Foundation, and the University of Memphis to their church to discuss existing conditions and future development possibilities for their South Memphis community. The Robinsons had spent 15 years and helped raise $\$ 15$ million to systematically rebuilding their congregation by serving the unmet "spirit, soul, and body" needs of the Greater South Memphis community. They listed several impressive accomplishments, including the expansion of their congregation from 300 to 1,500 members, establishing a community development corporation engaged in affordable housing and job training programs, and the launch of a family life center offering health and wellness services. They also re-organized the Ernestine Rivers Child Development Center as a state-designated "four-star" daycare facility and created the region's most successful (K-6th grade) charter elementary school between 1993 and 2008.

Notwithstanding these accomplishments, a variety of public health, socioeconomic, and physical conditions data sets documented their area's ongoing decline. The Robinsons asked those assembled what they felt the congregation could do to improve conditions in their historic African American neighborhood. The University of Memphis representatives argued that the congregation would have to significantly increase the scale of its efforts to counteract the powerful disinvestment and out-migration processes undermining their community. The urban anthropologists and planners representing the University encouraged the Robinsons to convene the majority of the African American schools, social service agencies, and religious groups to produce a comprehensive five-year development plan focused on the 140 residential blocks comprising the Greater South Memphis community.

The St. Andrew A.M.E. Church agreed to establish a neighborhood-wide sponsoring committee to create a South Memphis Revitalization Action Plan (SoMeRAP) when the University of Memphis and other attending organizations committed to providing needed planning and technical assistance and the Hyde Family Foundation offered to fund the expanded planning process. SoMeRAP's leaders were frustrated by past participation in labor-intensive planning efforts sponsored by the City of Memphis that produced few benefits for the community. They stressed the importance of taking quick and effective action to build broad-based support for the planning process and strong resident ownership of the resulting plan. Between August of 2008 and May of 2009, this new community coalition mobilized more than 500 
households, area businesses, and faith-based organizations to contribute to a highly participatory planning process that sought to build upon the community's many existing assets to address its most critical challenges.

\section{Goals and Objectives}

SoMeRAP's overarching goal was to reverse the long-term decline of South Memphis through the development, adoption, and implementation of an ambitious revitalization plan designed to transform this historic African American neighborhood into one of the region's premier communities of choice. The newly established coalition of community-based organizations sought to achieve this goal through a series of objectives, including (1) the mobilization of community-based organizations, social service agencies, municipal departments, and small businesses serving the area to provide effective stewardship of a highly participatory community planning process; (2) the expansion of educational, health care, employment, housing, and retail opportunities for community residents; (3) the recruitment of regional businesses and philanthropic foundations to implement significant elements of their proposed plan; (4) the creation of a replicable model of bottom-up/bottom-sideways planning that could be undertaken other poor and working-class communities in Memphis to stabilize/revitalize their neighborhoods (see Lambert-Pennington, 2010 and Lambert-Pennington, Reardon, Robinson and Church 2011 for an account on this project).

\section{Partnership Process}

The University of Memphis mobilized graduate students to design and implement a planning process using participatory action research methods (Greenwood \& Levin, 1998). During the 2008-09 academic year, students from the architecture, planning, and anthropology programs worked under the supervision of two South Memphis residents and two university faculty members to put together research designs, gather and analyze data, and present comprehensive development plans that addressed multiple topics.

During these nine months, University of Memphis students and their community partners succeeded in involving a broad cross-section of stakeholders to complete: (1) an examination of the historical origins, socioeconomic profile, and physical evolution of South Memphis using archival materials; (2) the analysis of recent population and housing trends for South Memphis using 1990 and 2000 U.S. Census data; (3) a visual analysis of the community's street layout, building architecture, urban design characteristics, and historical/cultural landscape and building resources via field surveys; (4) an inventory of land uses, building conditions, and site maintenance levels for more than 2,000 building lots through a parcel-by-parcel survey; (5) a summary and analysis of St. Andrew's leaders' perspectives on the church's role in the community, their understanding of existing neighborhood conditions, and their hopes regarding the community's future through twenty-four interviews; (6) an evaluation of community leaders' view of existing neighborhood conditions and their hopes regarding the area's future though fourteen institutional interviews and 
six focus groups; (7) a survey of residents' desires and preferences related to the design of a proposed childcare facility, community and cultural center, senior housing complex, and mixed-use neighborhood retail corridor; and, (8) a preliminary analysis of the safety and design quality of the primary routes area children take to school (Lambert-Pennington et al., 2011, p. 61).

Each month the data generated by these research activities were discussed and analyzed at Community Planning Meetings organized by St. Andrew Church to determine their policy implications. In April 2009, more than 120 residents and institutional leaders attended a daylong Neighborhood Summit, during which they formulated the basic framework for the "South Memphis Revitalization Action Plan: Building a More Vibrant, Sustainable and Just Community."

\section{Major Initiatives}

Between 2009 and 2011, the University of Memphis organized students from five studios in anthropology, architecture, and planning departments, as well as volunteer architects and landscape architects to support the community in carrying out the following initiatives: (1) the clearance of a highly visible corner lot, owned by St. Andrew's Church, for use as a seasonal farmers market, to partially remedy the food security challenges confronting residents; (2) the acquisition and transformation of Chateau-Kerr, a troubled market rate-housing complex close to St. Andrew Church, into a mixed-income, mixed-finance housing complex featuring a significant number of affordable and special needs housing units; (3) the restoration of a segment of John Nolen's celebrated South Parkway, which serves as the central corridor integrating South Memphis' many residential sub-divisions; (4) the re-purposing of a vacant public school as a cooperative medical and dental clinic to replace a recently closed municipal wellness center; (5) the transformation of an abandoned industrial rail line into a hiking and biking trail connected to the Mississippi River Trail Tennessee network. Additionally, and beyond the immediate benefit of the South Memphis community, the partnership (6) launched a grassroots leadership program with the assistance of The University of Memphis and the Highland Center for Citizen Education and Research, and (7) established a neighborhood-oriented retail center to recapture consumer spending currently taking place outside of the neighborhood (Reardon \& Raciti, 2018).

\section{Accomplishments}

Within 90 days of the neighborhood plan's approval by local planning authorities, SoMeRAP mobilized local social and economic assets to create the most successful neighborhood-based farmers' markets in the South (Hicks \& Lambert-Pennington, 2014). The South Memphis Farmers Market attracts an average of 600 shoppers every Thursday from April to October. It was featured as a "best practice" in faithbased development on the White House web page during the Obama Administration. More recently, SoMeRAP received funding to transform an abandoned service station on the market site into a full-service grocery store, commercial kitchen, and 
cooking school. Subsequentially, the success of the South Memphis Farmers Market prompted the City of Memphis to fund the restoration of the historic South Parkway.

SoMeRAP secured additional funding to construct a new building for the Ernestine Rivers Child Development Center, allowing them to double their enrollment. The transfer of these children to a nearby purpose-built facility, freed up sufficient space within the St. Andrew A.M.E. educational complex to enable the Circles of Success Charter School to add fourth, fifth, and sixth grades. The WORKS Inc. $\mathrm{CDC}$ also received new funding from the U.S. Department of Housing and Urban Development to significantly expand their home repair program for low-income seniors and persons with disabilities. With the assistance of a private developer, The WORKS Inc. was able to rehab dozens of single-family homes and small multi-family buildings within the community.

SoMeRAP, with the assistance of the University of Memphis students and faculty, produced a five-year comprehensive development plan that was endorsed by the community and unanimously approved by the City of Memphis and the Shelby County Land Use Control Board. In spite of this official recognition, it has been challenging for public institutions in Memphis to embrace this approach to community planning, which requires significant power-sharing with residents and leaders of underserved communities. An important take away from students working in the South Memphis project was about the ability of third-parties, such as universities, to shape strategies needed to enhance organizational capacity-building and new forms of leadership within community-based organizations engaged in project implementation (Lambert-Pennington \& Pfromm, 2010). The social learning process undergirding the South Memphis Project was instrumental in establishing similar initiatives in Memphis, which questioned taken for granted power dynamics within the city's mainstream planning and design efforts (Raciti, 2018; Raciti et al., 2016).

\section{Detroit Community-Academic Urban Research Center (Detroit URC)}

In the mid-1990s, the Centers for Disease Control and Prevention (CDC) funded three Urban Research Centers (URCs) to address health inequities in urban areas, including Detroit, Seattle, and New York City. The purpose of these URCs was to respond to local health priorities by creating partnerships between academic institutions, community-based organizations, local health departments, the CDC, community members and leaders, and other private and public organizations (Metzler et al., 2003). The Detroit URC grew out of the Community-Based Public Health Initiative (CBPH), an earlier collaboration between the University of Michigan School of Public Health and the Detroit Health Department, which was funded by the W.K. Kellogg Foundation (Israel et al., 2001). Based on this experience, the academic researchers and city health department leaders spent considerable time discussing the advantages and limitations of responding to the CDC's call for proposals for establishing URCs.

After finally deciding to pursue the grant, and with only eight days to write a proposal, they decided to be guided by the community-based research principles that had been initially developed as part of the Kellogg-funded CBPH Initiative (Schulz 
et al., 1998). They recognized that given the short time frame for preparing the proposal, they would not be able to follow some of the very principles they wanted to adhere to (e.g., involve community partners from the very beginning). Thus, the academic researchers and city health department team decided to submit a proposal to the CDC that would broadly address family and community health, which would allow for considerable flexibility in selecting priority issues once the community partners were involved. Given the large size and multiple communities that make up Detroit, the team also identified two communities to engage with, the lower Eastside and Southwest Detroit. The Eastside community was predominantly African American, and the Southwest community was home to the largest Latino population in the city, both had faced decades of severe socioeconomic and health challenges and had a history of strong social networks and community-based organizations (Israel et al., 2001). During the grant proposal writing stage, a set of criteria was identified for selecting potential partner organizations to invite to join the Detroit URC Board. These criteria were: (1) had some prior positive working relationship with either the university or the health department; (2) their work and mission was relevant to the proposed Center (e.g., interest in health issues); (3) were highly regarded in their communities; and (4) had a record of successful work in their field (Israel et al., 2001). These criteria have been refined during the last 25 years as organizations have joined or left the Board. The organizations were approached through written and oral communications, with no time available for face-to-face contact or involvement during the grant writing process. They were assured, and it was written into the proposal, that the first six months of the project would be spent engaging in partnership development (Israel et al., 2001).

Similar to ESLARP, the Detroit URC community partners were initially very skeptical about working with academic institutions and, as was revealed several years into the partnership, they initially agreed to participate to ensure that the University did not harm their communities, as previous researchers had done (Brakefield-Caldwell et al., 2015; Israel et al., 2001; 2006a, b; Lantz et al., 2001). After the proposal was funded, they participated in meetings to establish operating norms, the mission statement, and CBPR principles that would guide the project. Thus, began the development of new working relationships and trust-building, where community participation and influence are valued (Brakefield-Caldwell et al., 2015). The Board established a process evaluation initiative to assess the quality of the partnership itself, which led some initially skeptical community partners to become open to committing to an ongoing working relationship with the University. This willingness was contingent upon the relationship going beyond being a steering committee for a particular study. Instead, it would be a body with decision-making power from which more specific research, intervention, and advocacy efforts would flow (Brakefield-Caldwell et al., 2015; Lantz et al., 2001).

\section{Goals and Objectives}

The overarching goal of the Detroit URC is to promote CBPR partnerships that work to understand and tackle the social and physical environmental determinants of health as a strategy for promoting health equity. In contrast to the other two case 
studies presented here, the Detroit URC itself does not conduct CBPR research studies per se. Instead, they are an "umbrella" partnership that fosters multiple affiliated partnerships, some of which are almost as long-standing as the Detroit URC itself. Thus, the Center facilitates the establishment and enhances the capacity of research collaborations to use the knowledge gained in etiologic studies, as well as local community resources and strengths, in developing public health interventions and policies (Brakefield-Caldwell et al., 2015). The Detroit URC seeks to achieve the following goals through its numerous partnerships and activities: (1) foster, enhance, and sustain CBPR partnerships among academic institutions and Detroitbased organizations focused on promoting health equity; (2) increase the capacity of different partner institutions to promote health equity through CBPR; (3) strengthen the ability of all partners to engage in policy advocacy; (4) translate research findings to advance policy formulation, dissemination, and education; and (5) maintain, enhance, and sustain the Detroit URC. ${ }^{1}$

\section{Partnership Process}

At its inception, the Detroit URC Board was comprised of representatives of each of its partner organizations: Community Health \& Social Services Center, Inc., Friends of Parkside, Latino Family Services, Butzel Family Center, Kettering/Butzel Health Initiative, Warren Conner Development Coalition, the City of Detroit Health Department, Henry Ford Health System, the University of Michigan School of Public Health, and the CDC (Lantz et al., 2001). The Board met monthly, taking approximately 18 months (vs. six months projected in the proposal) to establish trust and mutual commitment, through the development of its operating norms, mission statement, and partnership principles. The Board is non-hierarchical (i.e., no president or executive committee), and it governs and guides the work of the Detroit URC in a way that is consistent with its partnership CBPR principles (Lantz et al., 2001). They also set priorities, wrote and submitted grant proposals, and developed affiliated partnerships to conduct specific CBPR studies (Israel et al., 2006a, b, 2001). In contrast to the URCs in NYC and Seattle, the Detroit URC Board is comprised of representatives from only community-based organizations (CBOs) and health and human service agencies, and not solely individual community members. This choice was a conscious decision made when selecting CBOs that are in and of the communities involved, with staff from the very communities. This embeddedness provides connections to many entities within a community that is broader than any individual is likely to have. Moreover, given that it is the organization that is the "member," if a given individual leaves an organization, another person within the organization is identified to sit on the Board. This ensures continuity within the partnership across the organizations involved.

The initial funding provided by $\mathrm{CDC}$ enabled the partnership building required for developing the Detroit URC Board from 1995 to 1999. This decision openly and directly acknowledged that community, academic, and practice partnerships involve

\footnotetext{
1 The Detroit URC Framework and Goals Factsheet is available at https://detroiturc.org
} 
time and resources for partners to get to know each other and build trust. Ultimately, this investment by the CDC helped facilitate the evolution of CBPR, which has emerged as an important and highly regarded research approach that now boasts dedicated journals, annual conferences, funding opportunities, and unique evaluation metrics (Israel et al., 2013; Wallerstein et al., 2018).

\section{Major Initiatives}

Over the last 25 years, the Detroit URC has grown and adapted (Israel et al., 2018). The Board governs the core functions ${ }^{2}$ and focuses on fostering and mentoring partnerships, training, and capacity-building in CBPR, and policy advocacy. They also provide small and medium grant opportunities to support partnership development and action. Central to the Center are its affiliated partnerships that are directly established out of the Detroit URC Board, receive structural and staff support from the Center, and include one or more Detroit URC board members in their steering committees. Each of these partnerships has steering committees that develop their own set of CBPR principles and operating procedures. Many have secured multiple rounds of funding for various projects, have contributed to enhanced knowledge and understanding of the social and physical environmental determinants of health inequities, and ultimately achieved concrete changes at multiple levels, e.g., individual, organizational, policy. Several of these affiliated partnerships are briefly described below.

1. East Side Village Health Worker Partnership (ESVHW) (est. 1995-2003) was the first partnership established. It developed a lay health advisor study and intervention program that examined and addressed stressors in the environment and their impact on short- and long-term health outcomes among women and children in Detroit (Parker et al., 1998; Schulz et al., 2002).

2. Community Action Against Asthma (CAAA) (est. 1999) has conducted epidemiological and intervention research on the environmental triggers of childhood asthma among African Americans, Arab Americans, and Latinos in Detroit and Dearborn, Michigan (Edgren et al., 2005; Parker et al., 2003).

3. Healthy Environments Partnership (HEP) (est. 2000) has conducted epidemiologic and intervention research on the social and physical environments and racial/ ethnic disparities in cardiovascular health among African American, Latino, and white residents (Israel et al., 2006b; Schulz et al., 2005)

4. The CBPR Partnership Academy (est. 2014) is a year-long program designed to help community-academic research teams working on racial/ethnic health inequities to learn how to use a CBPR approach in their communities. It includes a week-long intensive course taught at the University of Michigan in Ann Arbor, as well as structured learning, networking, and mentorship activities throughout the program year (Coombe et al., 2019b).

\footnotetext{
${ }^{2}$ Detroit URC Partnership Structure Diagram is available at https://detroiturc.org/partnerships.html
} 
5. Community Action to Promote Healthy Environments (CAPHE) (est. 2013) is a partnership that gathers air quality and related data and has translated it into a public health action plan that provides meaningful recommendations, and the implementation of strategies aimed at reducing and mitigating the impact of air pollution in Detroit (Schulz et al., 2018).

\section{Major Accomplishments}

Since 1995, the Detroit URC has fostered the establishment of over ten affiliated partnerships which have conducted more than 35 research projects focused on a number of social and physical environmental determinants of health (e.g., air pollution, housing, socioeconomic status) and health outcomes, including asthma, heart disease, diabetes, violence, access to health insurance, fresh food, and physical activity. Each affiliated partnership has its own steering committee, whose membership includes some Detroit URC board members, representatives of other community-based organizations, and community members that are not associated with specific organizations (Israel et al., 2001, 2006a, b; Lantz et al. 2001).

The Detroit URC and its affiliated partnerships have raised over $\$ 45$ million in external federal and foundation grants; helped train over 500 undergraduate, masters, and doctoral students, and post-doctoral scholars in public health, social work, nursing, psychology, anthropology, urban planning and other disciplines to undertake CBPR; hired and trained over 400 Detroiters as full and part-time staff; improved the health status of participants in CBPR intervention studies (Parker et al., 2008; Schulz et al., 2015); provided funding, skills building and mentoring opportunities for over 75 community-academic partnerships locally and nationally (Coombe et al., 2019a); conducted workshops for several thousand community and academic participants nationally and internationally; and developed multiple policies and advocacy training activities involving youth, community members, community organizations, and other stakeholders to enhance their capacity to conduct effective policy advocacy (Coombe et al., 2017; Israel et al., 2010). These initiatives have resulted in increased participation and leadership of youth in planning and decision-making, fostered networks and relationships across organizations, nurtured a new generation of CBPR researchers, and sustained a focus on using research as a tool to transform people's lives and communities (Coombe et al., 2019b; Israel et al., 2010, 2006a, b).

Affiliated partnerships have also had major impacts on local and regional health outcomes and community and urban planning. CAPHE has been actively involved in translating research findings to influence policy change. In 2012, the Detroit City Council approved the construction of the Gordie Howe International Bridge from the Delray neighborhood in Southwest Detroit to Ontario, Canada. For over a decade, the Southwest Detroit Community Benefits Coalition (CBC) mobilized community leaders, residents, and politicians from Detroit to address their concerns about the impacts of more industrial air pollution and ambient noise on the health of residents that would result from a new bridge in the community. In addition to their own truck and quality of life survey research, the $\mathrm{CBC}$ used air quality data collected over the years by CAAA and HEP (two of the Detroit URC affiliated partnerships that make up CAPHE), as well as new surveys and air monitoring activities 
conducted by CAPHE to benefit the quality of life of the residents. Incorporating the results of this data into the organizing efforts by the CBC led to a $\$ 48$ million dollar City-State agreement to (1) conduct a Health Impact Assessment of the Bridge, (2) continue to monitor different types of pollution that may stem from the construction of the bridge and once it is completed, (3) purchase new homes outside the area, and, (4) retrofit residents' homes to lessen exposure to the additional air and noise pollution that will result from increased traffic caused by the bridge. The first of three waves of the Health Impact Assessment has been completed by a team that included community and academic partners from CAPHE and the $\mathrm{CBC}$, with recommendations for additional policy changes to reduce adverse health and economic impacts for residents of the bridge area (Sampson et al., 2020).

\section{Lessons Learned from These Cases}

The cases presented are undoubtedly different in many respects. However, there are notable common factors that we believe have led to ongoing systematic change for students, communities, and academic institutions.

Resident-Led Process Each of these partnerships was initiated by and/or included well-established community-based organizations with experienced leadership committed to building what Fainstein (2010) described as the "Just City."

Long-Term Perspective These partnerships understood the time required to build trust among participating organizations, identify and define the issues to be addressed, formulate research designs to analyze the causes of these problems, design and implement interventions and policies to address these factors, and monitor and evaluate the impact of these efforts.

Commitment to Action These partnerships undertook a wide range of community organizing activities typically not undertaken by universities and community-based development corporations to influence the urban investment decisions of public and private institutions, which, to a large extent, determine the quality of life in lowincome rural and urban communities.

Skillful Use of Power These partnerships realized that careful analysis and thoughtful policy prescriptions designed to address specific urban problems was necessary but insufficient to effect social change. They had a clear understanding of the role that power and ideology plays in maintaining and/or changing policies.

Small Victories to Expand Resident Engagement and Enhance Community Support Each of these partnerships pursued a developmental approach to change using the momentum generated by highly visible, albeit limited impact reforms, to expand their non-partisan base of political support in order to successfully undertake more ambitious social reforms. 
Reflective Practice Each of these partnerships made structured reflection on their ongoing collaborative research and policy change activities, a defining characteristic of their work. Through this process, eloquently described by MIT's Don Schon (1984), they were able to systematically improve, over time, the effectiveness of their collaborative partnership, research methods and techniques.

Policy-Change Focus Each of these partnerships pursued or fostered research designed to advance redistributive policies aimed at reducing income, wealth, and power disparities within their regions and the nation. Each partnership sought to mobilize the intellectual, educational, communication, and non-partisan political power of colleges and universities to address important drivers of social inequality within our society.

Organizational Capacity-Building Each of these partnerships made the identification and development of new collaborative leaders, expansion of a popular base for progressive reform, and the development of "partnership" organizations with strong organizing, planning, and development capacity a primary goal of their efforts.

The Importance of State and Federal Support Two of the three partnerships (i.e., Detroit and East St. Louis) featured in this article received critical start-up funding from state and federal agencies, which enabled them to establish "proof of concept" for ambitious $\mathrm{C} / \mathrm{U}$ development partnerships.

\section{Promoting More Transformational Community/University Partnerships}

The incorporation of these principles into the work of current and future C/U partnerships could lay the foundation for a more transformational engaged scholarship aimed at combatting the most powerful generators of social inequality in our society. For example, colleges and universities can incorporate engaged scholarships activities in their pedagogical, diversification, and structural initiatives.

\section{Pedagogical}

- Encourage the large number of students who are engaged in tutoring in underperforming schools to carry out complementary research, educational, organizing, and advocacy efforts to establish a high quality, life long, public education as a human right as advocated by Bob Moses founder of the Algebra Project (algebra.org);

- Challenge students that are involved in post-disaster recovery efforts within environmental justice communities devastated by natural disasters to work with colleagues from other campuses to support the Green New Deal ${ }^{3}$ legislation aimed at reducing greenhouse gas emissions, a significant driver of extreme weather events;

\footnotetext{
${ }^{3}$ House Resolution 109. Submitted on February 7, 2019 to the $116^{\text {th }}$ Congress of the United States.
} 
- Have students involved in visitation, tutorial, and writing programs in jails and prisons to support law enforcement and judicial reforms needed to end the mass incarceration of African American men, such as those proposed by the Marshall Project (themarshallproject.org);

- Encourage students active in local food security efforts, such as organizing community gardens, farmers markets, and community-supported agriculture, to become active in a non-partisan public interest campaign to limit agribusiness mergers that make it increasingly difficult for small acreage, ranchers, and dairy farms to survive;

- Invite students to undertake research, organizing, and advocacy to support the enactment of the Food and Agribusiness Merger Moratorium and Antitrust Review Act of $2019^{4}$ to protect the future of small-scale agricultural producers;

\section{Diversification}

- Create and support a culture of anti-racism amongst the individuals, organizations and institutions involved in $\mathrm{C} / \mathrm{U}$ partnerships;

- Develop policies and programs that support recruitment and retention of students and faculty of color as participants and leaders of $\mathrm{C} / \mathrm{U}$ partnerships;

\section{Structural}

- Recognize the value of high-quality community-engaged and participatory research within tenure and promotion policies and processes;

- Establish reward structures that acknowledge the value placed on this work over and above tenure and promotion;

- Recognize and compensate community partners for their contribution to the research and teaching activities of $\mathrm{C} / \mathrm{U}$ partnerships; and,

- Intensify and broaden efforts to actively engage community partners in designing and managing the evaluation conducted to enhance the impact of $\mathrm{C} / \mathrm{U}$ partnerships.

Some of these suggestions require the development of curricula designed to assist students engaged in public service activities in low-income communities to critically examine the market dynamics, political ideologies, public policies, and governmental structures contributing to the inequities they are responding to through their direct service activities. It would also require the development of curricula that would expose students to the wide range of social change theories and methods, including community organizing, popular education, electoral reform, civil rights litigation, and policy reform available to address the key drivers of social inequality.

Other suggestions require for the nation's colleges and universities to commit themselves to secure the human and financial resources needed to support

\footnotetext{
${ }^{4}$ House Resolution 2933. Introduced on May 22, 2019 to the $116^{\text {th }}$ Congress of the United States.
} 
non-partisan public interest campaigns undertaken by students, researchers, and community partners committed to shifting their focus from direct service activities to changing the rules under which the major actors in our political economy operate that are responsible for exacerbating income, wealth, and power inequities in our society. The last six recommendations presented above feature suggestions for diversifying and recognizing faculty engaged in these efforts and acknowledging and rewarding the contribution community partners make towards enhancing the pedagogy of $\mathrm{C} / \mathrm{U}$ partnerships. Absent these kinds of transformational changes in the engaged scholarship sector of higher education, this movement will continue to offer "feel good" and "resume building" experiences for students, faculty and community partners who will continue to live in an increasingly inequitable society in which many residents will continue to experience poverty, powerlessness, and violence.

\section{Declarations}

Conflict of Interest Statement On behalf of all the authors, the corresponding author states that there is no conflict of interest.

Open Access This article is licensed under a Creative Commons Attribution 4.0 International License, which permits use, sharing, adaptation, distribution and reproduction in any medium or format, as long as you give appropriate credit to the original author(s) and the source, provide a link to the Creative Commons licence, and indicate if changes were made. The images or other third party material in this article are included in the article's Creative Commons licence, unless indicated otherwise in a credit line to the material. If material is not included in the article's Creative Commons licence and your intended use is not permitted by statutory regulation or exceeds the permitted use, you will need to obtain permission directly from the copyright holder. To view a copy of this licence, visit http://creativecommons.org/licen ses/by/4.0/.

\section{References}

Balassiano, K. (2011). Tackling "wicked problems" in planning studio courses. Journal of Planning Education and Research, 31(4), 449-460. https://doi.org/10.1177/0739456X11415282.

Benneworth, P. (2013). University engagement with socially excluded communities. In University Engagement with Socially Excluded Communities (pp. 3-31). Springer Netherlands. https://doi.org/ 10.1007/978-94-007-4875-0_1.

Birch, E., Perry, D. C., \& Taylor, H. L., Jr. (2013). Universities as Anchor Institutions. Journal of Higher Education Outreach and Engagement, 17(3), 7-14.

Boyer, E.L. (1990). Scholarship reconsidered: Priorities of the professoriate. Lawrenceville, NJ: Princeton University Press, Princeton Pike.

Boyer, E. L. (1996). The scholarship of engagement. Bulletin of the American Academy of Arts and Sciences, 49(7), 18-33.

Brakefield-Caldwell, W., Reyes, A. G., Rowe, Z., Weinert, J., \& Israel, B. A. (2015). Community partner perspectives on benefits, challenges, facilitating factors, and lessons learned from communitybased participatory research partnerships in Detroit. Progress in Community Health Partnerships: Research, Education, and Action., 9(2), 299-311.

Brownstein, R. (2020). American cities are staggeringly unequal!. The Atlantic. July 23, 2020.

Buys, N., \& Bursnall, S. (2007). Establishing university-community partnerships: Processes and benefits. Journal of Higher Education Policy and Management, 29(1), 73-86. https://doi.org/10.1080/13600 800601175797. 
Cameron, C., \& Wasacase, T. (2017). Community-driven health impact assessment and asset-based community development: An innovative path to community well-being. In Handbook of Community Well-Being Research (pp. 239-259). Springer.

Campbell, H. (2012). Lots of words... but do any of them matter? The challenge of engaged scholarship. Planning Theory and Practice, 13(3), 349-353. https://doi.org/10.1080/14649357.2012.711508.

Coombe, C. M., Israel, B. A., Reyes, A., Clement, J., Grant, S., Lichtenstein, R., et al. (2017). Strengthening community capacity in Detroit to influence policy change for health equity. Michigan Journal of Community Service Learning, 23(2), 101-116.

Coombe, C. M., Schulz, A. J., Brakefield-Caldwell, W., Gray, C., Guzman, R. J., Kieffer, E. C., et al. (2019b). Applying experiential action learning pedagogy to an intensive course to enhance capacity to conduct community-based participatory research. Pedagogy in Health Promotion: The Scholarship of Teaching and Learning. https://doi.org/10.1177/2373379919885975.

Coombe, C. M., Schulz, A. J., Guluma, L., Allen, A. J., Gray, C., Brakefield-Caldwell, W. et al. (2019a). Enhancing capacity of community-academic partnerships to achieve health equity: Results from the CBPR Partnership Academy. Health Promotion Practice, 21(4), 552-563.

Dirkx, J. M., Mezirow, J., \& Cranton, P. (2006). Musings and reflections on the meaning, context, and process of transformative learning: A dialogue between John M. Dirkx and Jack Mezirow. Journal of Transformative Education, 4(2), 123-139. https://doi.org/10.1177/1541344606287503.

Edgren, K. K., Parker, E. A., Israel, B. A., Lewis, T. C., Salinas, M. A., Robins, T. G., \& Hill, Y. R. (2005). Conducting a health education intervention and an epidemiological research project involving community members and community partner organizations: The Community Action Against Asthma project. Health Promotion Practice, 6, 263-269.

Ezeonwu, M., Berkowitz, B., \& Vlasses, F. R. (2014). Using an academic-community partnership model and blended learning to advance community health nursing pedagogy. Public Health Nursing, 31(3), 272-280. https://doi.org/10.1111/phn.12060.

Fainstein, S. F. (2010). The Just City (pp. 57-86). Cornell University Press.

Ferman, B., \& Hill, T. L. (2004). The challenges of agenda conflict in higher-education-community research partnerships: Views from the community side. Journal of Urban Affairs, 26(2), 241-257. https://doi.org/10.1111/j.0735-2166.2004.00199.x.

Gibbons, M. (2003). Self-directed learning handbook: Challenging adolescent students to excel. John Wiley Publishers.

Gorz, A. (1970). Strategy for labor: A radical proposal. Beacon Press.

Greenwood, D. J. \& Levin, M. (1998). Introduction to action research: Social research for social change. Thousand Oaks, CA: Sage Publications.

Healthy People (2030). U.S. department of health and human services, office of disease prevention and health promotion. Retrieved [July 15, 2020], from https://health.gov/healthypeople/objectives-anddata/social-determinants-health.

Hicks, K., Lambert-Pennington, K. (2014).Evaluating the South Memphis farmer's market as a strategy to improve access to healthy foods: Lessons from 2011. Journal of Agriculture, Food Systems, and Community Development, 1-15. https://doi.org/10.5304/jafscd.2014.042.014.

Israel, B. A., Coombe, C. M., Cheezum, R. R., Schulz, A. J., McGranaghan, R. J., Lichtenstein, R., et al. (2010). Community-based participatory research: A capacity-building approach for policy advocacy aimed at eliminating health disparities. American Journal of Public Health, 100(11), 2094-2102.

Israel, B. A., Eng, E., Schulz, A. J., \& Parker, E. A. (2013). Introduction to methods for CBPR for health. In B.A. Israel, E. Eng, A.J. Schulz, E.A. Parker (Eds.), Methods for Community-Based Participatory Research for Health (2nd). Jossey-Bass Publishers, Inc.

Israel, B. A., Krieger, J., Vlahov, D., Ciske, S., Foley, M., Fortin, P., et al. (2006a). Challenges and facilitating factors in sustaining community-based participatory research partnerships: Lessons learned from the Detroit, New York City and Seattle Urban Research Centers. Journal of Urban Health: Bulletin of the New York Academy of Medicine, 83(6), 1022-1040.

Israel, B. A., Lichtenstein, R., Lantz, P., McGranaghan, R., Allen, A., Guzman, J. R., et al. (2001). The Detroit Community-Academic Uurban Research Center: Development, implementation, and evaluation. Journal of Public Health Management and Practice, 7(5), 1-19.

Israel, B. A., Schulz, A. J., Estrada-Martínez, L., Zenk, S., Viruell-Fuentes, E., Villarruel, A. M., et al. (2006b). Engaging urban residents in assessing neighborhood environments and their implications for health.Journal of Urban Health, 83, 523-539. 
Israel, B. A., Schulz, A. J., Parker, E. A., \& Becker, A. B. (1998). Review of community-based research: Assessing partnership approaches to improve public health. Annual Review of Public Health, 19, 173-202.

Israel, B. A., Schulz, A. J., Parker, E. A., Becker, A. B., Allen, A. J., Guzman, J. R., \& Lichtenstein, R. (2018). On community-based participatory research. In: N. Wallerstein, B. Duran, J.G. Oetzel, and M. Minkler (Eds.), Community-Based Participatory Research for Health: Advancing Social and Health Equity. (Chapter 3). Jossey-Bass Publishers, Inc.

Jones, C. P. (2018). Preface. In N. Wallerstein, B. Duran, J.G. Oetzel, and M. Minkler (Eds.), CommunityBased Participatory Research for Health: Advancing Social and Health Equity. Jossey-Bass Publishers, Inc.

Lambert-Pennington, K. (2010). Practicing what we preach: the possibilities of participatory action research with faith-based organizations. NAPA Bulletin, 33(1), 143-160. https://doi.org/10.1111/j.1556-4797. 2010.01045.x.

Lambert-Pennington, K., \& Pfromm, J. (2010). Faith-based development and community renaissance: Tradition and transformation in South Memphis. In J. Bauer, J. Brashler, W. Cadge, A. Chivakos, ST. Fitzgerald, W. Garriott et al. Not by faith alone: Social services, social justice, and faith-based organizations in the United States. Lexington Books, Lexington, MA.

Lambert-Pennington, K., Reardon, K., Robinson, KS. (2011). Revitalizing South Memphis through an interdisciplinary community-university development partnership. Michigan Journal of Community Service Learning, 17(2), 59-70.

Lantz, P. M., Viruell-Fuentes, E., Israel, B. A., Softley, D., \& Guzman, J. R. (2001). Can communities and academics work together on public health research? Evaluation results from a community-based participatory research partnership in Detroit. Journal of Urban Health., 78(3), 495-507.

Metzler, M. M., Higgins, D. L., Beeker, C. G., Freudenberg, N., Lantz, P. M., Senturia, K. D., et al. (2003). Addressing urban health in Detroit, New York City, and Seattle through community-based participatory research partnerships. American Journal of Public Health, 93(5), 803-811.

Mezirow, J. (1991). Preface. Transformative dimensions of adult education. Jossey-Bass, Inc., Publisher, XI-XVIII.

Nye, N., \& Schramm, R. (1999). Building Higher Education-Community Development Corporation Partnerships. U.S. Department of Housing and Urban Development.

Parker, E. A., Israel, B. A., Robins, T. G., Mentz, G., Lin, X., Brakefield-Caldwell, W., et al. (2008). Evaluation of Community Action Against Asthma: A community health worker intervention to improve children's asthma-related health by reducing household environmental triggers for asthma. Health Education \& Behavior, 35, 376-395.

Parker, E. A., Israel, B. A., William, M., Brakefield-Caldwell, W., Lewis, T. C., Robins, T., et al. (2003). Community Action Against Asthma: Examining the partnership process of a community-based participatory research project. Journal of General Internal Medicine, 18, 558-567.

Parker, E. A., Schulz, A. J., Israel, B. A., \& Hollis, R. M. (1998). East Side Detroit Village health worker partnership: Community-based lay health advisor intervention in an urban area. Health Education \& Behavior, 25, 24-45.

Phillips, R., \& Wong, C. (2016). Handbook of Community Well-Being Research. International Handbook of Quality of Life. Springer Publishing Company.

Porter, L., Slade, C., Butt, A., Rosier, J., Perkins, T., Crookes, L., et al. (2015). Partnerships of learning for planning education Who is learning what from whom? The beautiful messiness of learning partnerships/Experiential learning partnerships in Australian and New Zealand higher education planning programmes/Res non verba? rediscovering the social purpose of planning (and the university): The Westfield Action Research Project/At the coalface, Take 2: Lessons from students' critical reflections/ Education for "cubed change"/Unsettling planning education through community-engaged teaching and learning: Reflections on the Indigenous Planning Studio. Planning Theory \& Practice, 16(3), 409-434.

Raciti, A. (2018). Urban Design as a Collective Enterprise: The challenge of housing development in Memphis (T.N., USA). Planning Practice and Research, 33(4), 392-408. https://doi.org/10.1080/02697459. 2018.1548137.

Raciti, A., Lambert-Pennington, K. A., \& Reardon, K. M. (2016). The struggle for the future of public housing in Memphis, Tennessee: Reflections on HUD's choice neighborhoods planning program. Cities, 57, 6-13. https://doi.org/10.1016/j.cities.2015.10.016. 
Reardon, K. (2000). An experiential approach to creating an effective community-university partnership: The East St. Louis Action Research Project. Cityscape, 5(1), 59-74.

Reardon, K. (2003). Ceola's vision, our blessing: The story of an evolving community/university partnership in East St. Louis, Illinois. In B. J. Eckstein \& J. A. Throgmorton (Eds.), Story and sustainability: Planning, practice, and possibility for American cities (pp. 114-142). MIT Press.

Reardon, K. M. (1997). Institutionalizing community service learning at a major research university: The case of the East St. Louis Action Research Project. Michigan Journal of Community Service Learning, $4(1), 130-135$.

Reardon, K. M. (2005). Empowerment planning in East St. Louis, Illinois. City, 9(1), 85-100. https://doi.org/ $10.1080 / 13604810500128629$.

Reardon, K. M. (2006). Promoting reciprocity within community/university development partnerships: Lessons from the field. Planning Practice and Research, 21(1), 95-107. https://doi.org/10.1080/02697 450600901566.

Reardon, K. M. (2019). Building Bridges: Community Partnerships in East St. Louis. Social Policy Press.

Reardon, K. M. \& Raciti, A. (2018). Building the progressive city one neighborhood at a time: The story of the East St. Louis Action Research Project USA. Power and Terrain of Ambiguity in Self-Organization Today. Tracce Urbana. University of Sapienza, pp. 69-105.

Rhoads, R. A., \& Howard, J. P. F. (1998). Academic service learning. Jossey-Bass Publishers.

Rittel, H. W., \& Webber, M. M. (1973). Dilemmas in a general theory of planning. Policy Sciences, 4(2), $155-169$.

Sampson, N., Sagovac, S., Schulz, A. J., Fink, L., Mentz, G., Reyes, A. G., et al. (2020). Mobilizing for community benefits to assess health and promote environmental justice near the Gordie Howe International Bridge. International Journal of Environmental Research and Public Health., 17(13), 4680. https://doi. org/10.3390/ijerph17134680.

Schön, D. (1984). The Reflective Practitioner: How Processionals Think in Action (pp. 27-85). Basic Books.

Schulz, A. J., Israel, B. A., Mentz, G. B., Bernal, C., Caver, D., de Majo, R., et al. (2015). Effectiveness of a walking group intervention to promote physical activity and cardiovascular health in predominantly non-Hispanic Black and Hispanic urban neighborhoods: Findings from the Walk Your Heart to Health Intervention. Health Education \& Behavior, 42(3), 380-392.

Schulz, A. J., Israel, B. A., Selig, S. M., and Bayer, I. S. (1998). Development and implementation of principles for community-based research in public health. In R.H. MacNair (Ed.), Research Strategies for Community Practice. Haworth Press.

Schulz, A. J., Kannan, S., Dvonch, J. T., Israel, B. A., Allen, A., James, S. A., et al. (2005). Social and physical environments and disparities in risk for cardiovascular disease: The Healthy Environments Partnership conceptual model. Environmental Health Perspectives, 113, 1817-1825.

Schulz, A. J., Mentz, G. B., Sampson, N., Ward, M., Dvonch, J. T., de Majo, R., et al. (2018). Independent and joint contributions of fine particulate matter exposure and population vulnerability to mortality in the Detroit metropolitan area. International Journal of Environmental Research and Public Health, 15(6), 1209

Schulz, A. J., Parker, E. A., Israel, B. A., Allen, A., Decarlo, M., \& Robinson, M. (2002). Addressing social determinants of health through community-based participatory research: The East Side Village Health Worker Partnership. Health Education \& Behavior, 29, 326-341.

Seifer, S.D., Wonger, K., Gelmon, S.B., \& Lederer, M. (2009). The community-engaged scholarship for health collaborative: A national change initiative focused on faculty roles and rewards. Metropolitan Universities, 20(2), 5-21.

Syme, S. L., \& Ritterman, M. L. (2009). The importance of community development for health and wellbeing. Community Development Investment Review, 5(3), 1-13.

Trickett, E. J., \& Rauk, L. (2019). Community well-being, community intervention and community development. In J. Page-Reeves (Ed.), Well-being as a multidimentinal concept: Understanding connections among culture, community and health (pp. 75-98). Lexington Books.

Wallerstein, N. \& Duran, B. (2018). Theoretical, historical, and practice roots of CBPR. Community-Based Participatory Research for Health: Advancing Social and Health Equity. In N. Wallerstein, B. Duran, J.G. Oetzel, \& M. Minkler (Eds.) Community-Based Participatory Research for Health: Advancing Social and Health Equity. Chapter 2. Jossey-Bass Publishers, Inc. 
Wallerstein, N., Duran, B., Oetzel, J. G., \& Minkler, M. (2018). On community-based participatory research. In N. Wallerstein, B. Duran, J.G. Oetzel, \& M. Minkler (Eds.) Community-Based Participatory Research for Health: Advancing Social and Health Equity. Chapter 1. Jossey-Bass Publishers, Inc.

Winthrop, R \& Dusst, E. (2020). Can universities be engines of sustainable development: A conversation with Judith Rodin. Brookings Education Plan Development Series. February 10, 2020.

Whyte, W. F. (1982). Social inventions for human problem solving: American Sociological Association, 1981 Presidential Address. American Sociological Review, 47, 1-18.

Publisher's note Springer Nature remains neutral with regard to jurisdictional claims in published maps and institutional affiliations. 